\title{
Editorial
}

\section{The Australasian information services industry in 1989}

INFORMATION ONLINE 89 was a considerable success, professionally, intellectually, socially and financially. More than 600 delegates attended, in the immediate wake of the Australian Bicentennial. Over 1500 members of the general public viewed the exhibition.

We are pleased that a number of the papers presented at Information Online 89 will reach a wider audience through a special issue of Information Services \& Use. Space precludes publication of all 29 papers which were presented at the conference. Ten of those papers are included in this issue.

Two of the papers address the growth of the online industry in the Australasia region. Writing as an independent consultant and Secretary of the Australian Database Development Association, Sherrey Quinn presented an authoritative view of the state of the database industry in Australia and New Zealand. Her paper reports the results of the latest in a series of ADDA surveys of database producers. From it, the reader can gain an appreciation of the size and composition of the industry in this region. Mr. Edward Huck-Tee Lim, University Librarian of Monash University in Victoria, presented an overview of networking activities in the ASEAN (Association of Southeast Asian Nations) region. His discussion focused on structural changes in the economies of ASEAN countries, on improvements in the growth in the telecommunications industries, and on a pervading realization that information is a strategic resource, that there is a need for ASEAN members to achieve self-sufficiency in the provision of information.

Several papers addressed subjects which added perspectives and depth in areas which added distinction to the conference programme. Mr. Peter Leonard and Ms. Peta Spender, practising solicitors, presented a paper dealing with the contractual and intellectual property protection of databases, an area in which they are professionally active. Mr. Keith Bell, Senior Surveyor at the Australian Surveying and Land Information Group, described efforts by the Commonwealth Government to coordinate information about Commonwealth land, which is held by almost all of its agencies. Professor K. Lyons and Dr. P. Sharma of the Department of Geographical Sciences at the University of Queensland, classified 
available land information systems, and discussed opportunities and obstacles to the development of more effective systems.

Technological opportunities to enhance the provision of information were highlighted by several papers. Mr. Jim Jarvis, Principal Research Scientist at the Australian Road Research Board, described knowledge-based systems and their possible relationships with databases. He related project selection criteria and developmental steps undertaken in a project which he brought to completion. Mr. Dennis Warren, Subject Librarian at Monash University addressed the rationale and identified key issues in deploying CD-ROM information products in academic libraries. Mr. Ian Smith, Information Services Librarian at the University of Melbourne, spoke and wrote about the need for and issues of evaluation of CD-ROM products in the library user services environment. Mr. Alan Ventress, Collection Development Librarian at the State Library of New South Wales, described the desirability and feasibility of distribution of CD-ROM products to multiple users through available information technology, thereby obtaining greater value from the information product.

The paper by Mr. Malcolm McPherson, Ms. Chris Harrap, and Ms. Jan O'Reilly of the Materials Research Laboratory, Defence Science and Technology Organisation, echoed a theme common to a number of papers: that of improving the information product we deliver.

The Conference was best summed up by Mr. David Batty, President of CDB Enterprises in the United States, who characterised the papers as falling into three categories: reviewing the state of the art and current practice in the online industry, looking critically and imaginatively at the future development and use of online services in Australasia, and emphasising a new concentration on a framework of reality in which online development and services are looked at in economic terms.

These papers represent the vitality and imagination of the information services industry in Australia and the Pacific area at a time of rising regional influence in world economic development. We are pleased at this opportunity to reach a global audience. 